\title{
Validity and Reliability of Metacognitive Rating Scale for Nursing Students
}

\author{
Lee, Kyunghee ${ }^{1} \cdot$ Heo, Youngjin ${ }^{2} \cdot$ Han, Mihwa $^{3} \cdot \mathrm{Kim}_{\text {Mijung }}{ }^{4} \cdot$ Choi, Hyunseok $^{5}$ \\ ${ }^{1}$ Professor, College of Nursing, Keimyung University, Daegu \\ ${ }^{2}$ Researcher, Industry-Academic Cooperation Foundation, Keimyung University, Daegu \\ ${ }^{3}$ Professor, College of Nursing, Sunlin University, Pohang \\ ${ }^{4}$ Outpatient Instructor, College of Nursing, Masan University, Masan \\ ${ }^{5}$ Professor, Center for Educational Performance, Keimyung University, Daegu, Korea
}

\begin{abstract}
Purpose: The aim of this study was to determine the reliability and validity of the metacognition rating scale (MCRS), which is a revised version of the existing metacognition questionnaire (MCQ) with anger and anxiety added. Methods: A survey was conducted on 591 nursing students at colleges in North and South Gyeongsang Provinces, South Korea. The collected data were processed for the reliability and validity of the MCRS through Cronbach's $\alpha$ and confirmatory factor analysis using SPSS 26.0. Results: Cronbach's $\alpha$ for the reliability of MCRS was calculated at $.88, .86, .77, .74$, and .66 for five subfactors. Among the five subfactors, the first, second, third, and fifth factors showed high correlation in each of six items. Factor 4 was highly correlated in 5 out of 6 questions. Conclusion: The data confirm that the MCQ revised to include anger and anxiety is both reliable and valid for nursing students. Therefore, this scale can be used to identify the maladaptive metacognition of nursing students in stressful situations.
\end{abstract}

Key Words: Metacognition; Student, Nursing; Learning; Anxiety

\section{INTRODUCTION}

\section{Background}

Metacognition refers to the awareness, knowledge, and control ability of one's own cognition. If cognition is an intellectual activity for processing a certain task, metacognition refers to the activity of monitoring such cognitive activity [1,2]. In other words, metacognition refers to psychological structures, knowledge, events, and processes related to the control, modification, and interpretation of thinking itself [3]. This capacity allows them to plan, control, and check their learning and to determine how to apply previously acquired knowledge and experiences [1,4]. For nursing students, metacognitive competence is the ability to assess outcomes of their nursing actions based on their own cognition as health care providers, make composite plans, and evaluate the results [2]. Metacognition serves as an important variable in learning, and students who show higher levels show greater academic success as well [5].

Because nursing students invest years in learning to execute high-level nursing actions in health care practice, they can experience stress and anger from, for example, strict learning environments that can lead to negative emotional responses such as anxiety, depression, and lowered self-esteem [6-9]. It would clearly be advantageous, therefore, to improve the metacognitive competence of nursing students and assist them with their learning achievement.

The self-regulatory executive function (S-REF) model, which explains metacognition, recognizes that dysfunctional metacognitive beliefs occur based on the people's type of response to negative thoughts and emotions, namely cognitive attentional syndrome (CAS) $[10,11]$. In the self-regulating executive function model, maladaptive beliefs are caused by a series of psychological processes called cognitive-attentional syndrome (CAS). CAS includes three main processes, each of which constructs extended

\footnotetext{
Corresponding author: Heo, Youngjin https://orcid.org/0000-0003-0100-8701

Industry-Academic Cooperation Foundation, Keimyung University, 1095 Dalgubeol-daero, Dalseo-gu, Daegu 42601, Korea. Tel: +82-53-580-6101, Fax: +82-53-715-2021, E-mail: hoho321@hanmail.net
}

- This work was supported by the National Research Foundation of Korea (NRF) grant funded by the Korea government (No. NRF-2020R1A2C1009207).

Received: May 23, 2021 | Revised: Aug 9, 2021 | Accepted: Sep 14, 2021

This is an open access article distributed under the terms of the Creative Commons Attribution Non-Commercial License (http://creativecommons.org/licenses/ by-nc/3.0), which permits unrestricted non-commercial use, distribution, and reproduction in any medium, provided the original work is properly cited. 
thinking in response to negative thoughts [10]. Control, a way of coping with stress that is described as suppression of thinking, is closely related to aggression, and aggressive behavior can arouse anger [12,13]. Metacognition as the highest area of cognition can have impacts on both behavior and affect as well as on cognition [14], and worry and anxiety are associated with each other in the cognitive process [15].

Metacognition is a high-level psychological structure conceptualized as an ability to perceive and control one's own thinking process and beliefs [16], and we devised the metacognitive rating scale, MCRS to measure diverse facets of metacognition. The tools for measuring metacognition in previous studies are as follows. Klein's [17] metacognitive questionnaire consisted of the subfactors of cognitive strategy, planning, and self-examination, and Schraw and Dennison's [18] metacognitive awareness inventory consisted of cognition knowledge and cognition control. Lee Ji Hye's [19] metacognitive measurement test consists of the subfactors of planning, inspection, and control. The Metacognitive Questionnaire (MCQ) developed by Cartwright-Hatton and Wells [15] is needed to measure the maladaptive metacognitive beliefs to grasp nursing student's psychological aspects such as anxiety, anger and impulse control due to academic stress.

The MCQ was developed with 65 items to determine levels of metacognition loaded onto five factors: positive beliefs about worry, negative beliefs about the uncontrollability of thoughts and corresponding danger, cognitive confidence, beliefs about the need to control thoughts, and cognitive self-consciousness [15]. The same authors developed a 30-item short form of the questionnaire (MCQ-30) that consists of items with the highest loading among the subfactors [3]. Seol [20] translated the MCQ-30 for use in South Korea, and K-MCQ-30 has been actively used by researchers for general college students, but there has been little research among nursing students in South Korea.

Although the MCQ-30 is a simpler, but still multidimensional, measure of metacognition that is more efficient than the full MCQ, the factor analysis at the time of its development showed weak associations on one of the subfactors. Specifically, only three of the six items for the subfactor beliefs about the need to control thoughts were highly associated, and the other three ("It is bad to think certain thoughts", "If I did not control a worrying thought and then it happened, it would be my fault", "I will be punished for not controlling certain thoughts") associations were weak [3]. In a study using K-MCQ-30, it was found that there were items with low correlation among the subfactors [21]. Therefore, more in-depth research on this topic was warranted, and we undertook this study. For the study, we revised items related to beliefs about the need to control thoughts with a focus on the adverse effects of thought control, so that the adverse effects could be associated with anger expressed as aggressive impulses $[12,13]$. Based on the MCQ [15], MCQ-30 [3], and K-MCQ -30 [20], we conducted this study to reliability and validity a metacognitive rating scale (MCRS) that we revised to include the concepts of anger and anxiety, emotions nursing students might experience during high-intensity academic work.

\section{Purpose}

We aimed to test the reliability and validity of the metacognitive rating scale (MCRS) revising and supplementing the MCQ-30.

\section{METHODS}

\section{Study Design}

The authors designed this study to test a revised version of the MCQ-30, the MCRS, among a group of nursing students in South Korea. The MCRS contained added measurements of anger and anxiety, potentially common emotions among nursing students.

\section{Research Procedure and Scale Adaptation Process}

Before we conducted this study, we also obtained permission from authors of the MCQ and the MCQ-30, KMCQ-30. We tested the revised scale, the MCRS, for reliability and performed confirmatory factor analysis (CFA) to confirm that the subfactors divided into components with the same concepts as the established scale.

Notices were posted on notice boards in the nursing departments at four colleges in North and South Gyeongsang Provinces, South Korea, seeking volunteers to participate in our study. The investigators obtained a signature from the participant on a written informed consent document. We also provided an explanation of the purpose and methods of this study in the preface of the questionnaire we distributed. We explained to the participants that they could discontinue participating and refuse to answer any more questions at any time. We also explained to participants that psychological counseling could be provided if any items on the cognitive scale triggered emotional difficulties, and the participants were instructed to contact the researcher immediately in that event. 


\section{Subjects and Data Collection}

Before we began the data collection, we obtained approval from the institutional review board of Keimyung University (IRB No. 40525-202011-HR-069-03). Using G*Power 3.1.9, we calculated the number of study subjects as 600 based on significance of 0.05 , effect size of 0.3 , power of 0.80 , and a previous study [21] of 662 college students based on the MCQ-30 factor structure. We distributed a total of 620 copies of the MCRS to male and female nursing students we received 603 completed copies, for a $97.3 \%$ return rate. We excluded 12 surveys that were incomplete or that did not clearly indicate the respondent's written consent, leaving 591 completed surveys for analysis.

\section{Measurement Tool}

MCRS is a revised version of the MCQ developed by Cartwright-Hatton and Wells [15] and its short forms, the MCQ-30 [3] and K-MCQ-30 [20]. Therefore, we added anger and anxiety to the MCQ-30 to develop the MCRS, and we revised a total of seven items: "I easily get angry when I feel irritated", "I always try to suppress my anger", "It is my weakness that I cannot control my anger", "I cannot control expressions of anger", "Expressing anger is bad", "I can express anger in words that are not aggressive", and "When you become addicted to worry, even the slightest amount of stress lead to anxiety".

The scale had a total of 30 items and consisted of a 5-point scale, and the degree of agreement with each item was rated on a Likert scale ranging from 1 point for "strongly disagree" to 5 points for "strongly agree". The questionnaire items were divided into five subfactors: positive belief in worry (POS; six items), negative belief that worries are uncontrollable and dangerous (NEG; six items), cognitive confidence (CC; six items), need for control-personality tendency (NC; six items), and cognitive self-consciousness (CSC; six items). The Cronbach's $\alpha$ for the reliability of the MCQ ranged from .72 to .89 at the time of its development and from .66 to .88 in this study.

\section{Analysis}

We used SPSS 26.0 software to process the survey data we collected. Specifically, we calculated descriptive statistics, two-sample t-test, and analysis of variance (ANOVA), estimated reliability with Cronbach's $\alpha$, and performed CFA to check validity. We also calculated Pearson's correlation coefficients for correlations among the five subfactors.

\section{RESULTS}

\section{Demographic Characteristics}

Of the 591 participants in this study, most were women ( $83.1 \%$ versus $16.9 \%$ men), most were high school graduates $(90.7 \%$ compared with $9.3 \%$ college graduates or higher), and their mean age was 21.7 years.

\section{Reliability and Validity Analysis}

We performed confirmatory factor analysis to measure the reliability and validity of the MCRS and used principal component analysis to simplify relevant variables and characterize each factor; the number of factors was determined base on eigenvalue $\geq 1$, and we used varimax rotation in the factor analysis. Table 1 presents the Cronbach's $\alpha$ reliability findings for the MCRS.

For factor 1 (POS), Cronbach's $\alpha$ was .77, which indicated reliability, whereas total cumulative variance was low $(47.2 \%)$, which partially met criteria for validity. For factor 2, NEG, Cronbach's $\alpha=.88$, eigenvalue $\geq 1$, and total cumulative variance $=62.7 \%$, which indicated validity and reliability. For factor 3, CC, Cronbach's $\alpha=.86$, which indicated reliability, and total cumulative variance $=59.2 \%$, which partially indicated validity. For factor $4, \mathrm{NC}$, Cronbach's $\alpha=.66$, indicating reliability, and total cumulative variance $=42.5 \%$, which partially indicated validity. For factor 5, CSC, Cronbach's $\alpha=.74$, indicating reliability, and total cumulative variance $=44.1 \%$, which partially indicated validity. CFA revealed that the first factor had high correlations in the order of items 19, 10, 7, 1, 28, and 23. In the second factor, items $9,21,11,4,2$, and 15 showed high correlations in that order. Under factor 3, items 17, 26, $8,29,24$, and 14 were highly correlated, and in factor 4 , items 22, 20, 6, 25, and 13 items were highly correlated. However, we found no high correlations for 27 items. Under the fifth factor, items $16,12,30,18,3$, and 5 correlated highly correlated in that order. In short, reliability was indicated for all five factors, POS, NEG, CG, NC, and CSC, but validity was only partially confirmed (Table 1).

\section{Mean Difference Test}

The mean difference test results for gender and education are presented in Table 2 . We found no statistically significant differences among POS, NEG, CC, NC, or CSC by gender, although high school graduates scored statistically significantly higher for POS than did college graduates. 
Table 1. Factor Structure and Reliability and Validity of MCRS

\begin{tabular}{|c|c|c|c|c|c|c|}
\hline \multirow{2}{*}{ Factors } & \multirow{2}{*}{ Items } & \multicolumn{5}{|c|}{ Loading on Factors } \\
\hline & & 1 & 2 & 3 & 4 & 5 \\
\hline \multirow{6}{*}{$\begin{array}{l}\text { Factor 1: } \\
\text { positive belief in } \\
\text { worry }\end{array}$} & 19. Worrying helps me cope & .84 & & & & \\
\hline & 10. Worrying helps me to get things sorted out in my mind & .80 & & & & \\
\hline & 7. I need to worry in order to remain organized & .65 & & & & \\
\hline & 1. Worrying helps me to avoid problems in the future & .65 & & & & \\
\hline & 28. I need to worry in order to work well & .61 & & & & \\
\hline & 23. Worrying helps me to solve problems & .52 & & & & \\
\hline \multirow{6}{*}{$\begin{array}{l}\text { Factor 2: } \\
\text { negative belief that } \\
\text { worries are } \\
\text { uncontrollable and } \\
\text { dangerous }\end{array}$} & 9. My worrying thoughts persist, no matter how I try to stop them & & .88 & & & \\
\hline & 21. When I start worrying I cannot stop & & .86 & & & \\
\hline & 11. I cannot ignore my worrying thoughts & & .80 & & & \\
\hline & $\begin{array}{l}\text { 4. When you become addicted to worry, even the slightest amount of } \\
\text { stress lead to anxiety }\end{array}$ & & .77 & & & \\
\hline & 2. My worrying is dangerous for me & & .76 & & & \\
\hline & 15. My worrying could make me go mad & & .66 & & & \\
\hline \multirow{6}{*}{$\begin{array}{l}\text { Factor 3: } \\
\text { cognitive } \\
\text { confidence }\end{array}$} & 17. I have a poor memory & & & .84 & & \\
\hline & 26. I do not trust my memory & & & .83 & & \\
\hline & 8. I have little confidence in my memory for words and names & & & .81 & & \\
\hline & 29. I have little confidence in my memory for actions & & & .78 & & \\
\hline & 24. I have little confidence in my memory for places & & & .72 & & \\
\hline & 14. My memory can mislead me at times & & & .60 & & \\
\hline \multirow{6}{*}{$\begin{array}{l}\text { Factor 4: } \\
\text { need for control }\end{array}$} & 22. I cannot control expressions of anger & & & & .86 & \\
\hline & 20. It is my weakness that I cannot control my anger & & & & .84 & \\
\hline & 6. I easily get angry when I feel irritated & & & & .74 & \\
\hline & 25. Expressing anger is bad & & & & .58 & \\
\hline & 13. I always try to suppress my anger & & & & .46 & \\
\hline & 27. I can express anger in words those are not aggressive & & & & .05 & \\
\hline \multirow{6}{*}{$\begin{array}{l}\text { Factor 5: } \\
\text { cognitive } \\
\text { self-consciousness }\end{array}$} & 16. I am constantly aware of my thinking & & & & & .80 \\
\hline & 12. I monitor my thoughts & & & & & .73 \\
\hline & 30. I constantly examine my thoughts & & & & & .68 \\
\hline & 18. I pay close attention to the way my mind works & & & & & .65 \\
\hline & 3. I think a lot about my thoughts & & & & & .58 \\
\hline & $\begin{array}{l}\text { 5. I am aware of the way my mind works when I am thinking } \\
\text { through a problem }\end{array}$ & & & & & .51 \\
\hline Eigenvalue & & 2.83 & 3.76 & 3.55 & 2.55 & 2.64 \\
\hline Cumulative \% & & 47.2 & 62.7 & 59.2 & 42.5 & 44.1 \\
\hline Cronbach's $\alpha$ & & .77 & .88 & .86 & .66 & .74 \\
\hline
\end{tabular}


Table 2. Mean Difference Test by Gender and Education

$(N=591)$

\begin{tabular}{lccccllccc}
\hline Factor & Gender & $\mathrm{n}$ & $\mathrm{M} \pm \mathrm{SD}$ & $\mathrm{t}(p)$ & Factor & Education & $\mathrm{n}$ & $\mathrm{M} \pm \mathrm{SD}$ & $\mathrm{t}(p)$ \\
\hline POS & $\mathrm{M}$ & 100 & $17.54 \pm 4.68$ & -0.24 & POS & High school & 536 & $17.75 \pm 4.40$ & 2.02 \\
& $\mathrm{~F}$ & 491 & $17.66 \pm 4.30$ & $(.809)$ & & College & 55 & $16.51 \pm 3.77$ & $(.044)$ \\
NEG & $\mathrm{M}$ & 100 & $14.88 \pm 5.76$ & -1.63 & $\mathrm{NEG}$ & High school & 536 & $15.84 \pm 5.63$ & 1.78 \\
& $\mathrm{~F}$ & 491 & $15.88 \pm 5.56$ & $(.104)$ & & College & 55 & $14.44 \pm 5.19$ & $(.076)$ \\
$\mathrm{CC}$ & $\mathrm{M}$ & 100 & $12.83 \pm 4.60$ & 0.26 & $\mathrm{CC}$ & High school & 536 & $12.75 \pm 4.83$ & 0.56 \\
& $\mathrm{~F}$ & 491 & $12.69 \pm 4.93$ & $(.794)$ & & College & 55 & $12.36 \pm 5.21$ & $(.575)$ \\
$\mathrm{NC}$ & $\mathrm{M}$ & 100 & $12.77 \pm 3.93$ & -1.13 & $\mathrm{NC}$ & High school & 536 & $13.13 \pm 4.00$ & -0.95 \\
& $\mathrm{~F}$ & 491 & $13.27 \pm 4.01$ & $(.258)$ & & College & 55 & $13.67 \pm 3.97$ & $(.340)$ \\
$\mathrm{CSC}$ & $\mathrm{M}$ & 100 & $17.78 \pm 4.36$ & -0.88 & $\mathrm{CSC}$ & High school & 536 & $18.18 \pm 4.28$ & 1.05 \\
& $\mathrm{~F}$ & 491 & $18.19 \pm 4.25$ & $(.378)$ & & College & 55 & $17.55 \pm 4.20$ & $(.292)$ \\
\hline
\end{tabular}

POS=Positive belief in worry; NEG=Negative belief that worries are uncontrollable and dangerous; $\mathrm{CC}=\mathrm{Cognitive}$ confidence; $\mathrm{NC}=$ Need for control; CSC $=$ Cognitive self-consciousness.

Table 3. Correlation Analysis of Subfactors

$(N=591)$

\begin{tabular}{|c|c|c|c|c|c|}
\hline Variables & POS & NEG & $\mathrm{CC}$ & $\mathrm{NC}$ & CSC \\
\hline POS & 1 & & & & \\
\hline NEG & $.69^{* *}$ & 1 & & & \\
\hline $\mathrm{CC}$ & $.28^{* *}$ & $.45^{* *}$ & 1 & & \\
\hline $\mathrm{NC}$ & $.40^{* *}$ & $.57^{* *}$ & $.54^{* *}$ & 1 & \\
\hline CSC & $.64^{* *}$ & $.69^{* *}$ & $.28^{* *}$ & $.46^{* *}$ & 1 \\
\hline
\end{tabular}

POS=Positive belief in worry; NEG=Negative belief that worries are uncontrollable and dangerous; $C C=C$ ognitive confidence; $N C=$ Need for control; CSC $=$ Cognitive self-consciousness; ${ }^{* *} p<.01$.

\section{Correlation Analysis among MCRS Subfactors}

Table 3 presents the correlation analysis findings based on the composite scores for the five scale subfactors in MCRS is presented in. Correlations were positive among all the subfactors, with POS and NEG, NEG and CSC being most strongly correlated at $r=.69$ and POS and CC, CC and CSC being least correlated at $\mathrm{r}=.28$.

\section{DISCUSSION}

For this study, we tested a scale we devised, the MCRS, for reliability and validity. We calculated favorable reliabilities of .66 to .88 , which were similar to or slightly lower than reliabilities seen with the MCQ [15], the MCQ-30 [3], the MCQ-30 in Turkey [22], and the K-MCQ-30 [20].

We used CFA to confirm that the scale consisted of five subfactors that correlated with one another (as with MCQ and MCQ-30) but were conceptually differentiated, and as we established earlier, all five subfactors were partially validated. CFA confirmed that all six items under factor 1 (POS) correlated closely: "Worrying helps me to avoid problems in the future", "I need to worry in order to remain organized", "Worrying helps me to get things sorted out in my mind", "Worrying helps me cope", "Worrying helps me to solve problems", and "I need to worry in order to work well".

We revised the core belief under factor 2, NEG, "I could make myself sick with worrying" to instead be, "When you become addicted to worry, even the slightest amount of stress lead to anxiety”. This revised item incorporated the concept of anxiety, had a factor loading of .77, and was validated. Six closely correlated items loaded under NEG: "My worrying is dangerous for me", "When you become addicted to worry, even the slightest amount of stress lead to anxiety", "My worrying thoughts persist, no matter how I try to stop them", "I cannot ignore my worrying thoughts", "My worrying could make me go mad", and "When I start worrying I cannot stop". The revised item was closely associated with factor 2, NEG, along with other items containing the concept of worry, which is supported by earlier research findings that worry and anxiety vulnerability are associated with each other [15].

CFA confirmed that all six items that loaded under fac- 
tor 3, CC, were closely associated: "I have little confidence in my memory for words and names", "My memory can mislead me at times", "I have a poor memory", "I have little confidence in my memory for places", "I do not trust my memory", and "I have little confidence in my memory for actions".

We revised the six items under factor 4, NC, to involve anger as a way of expressing the "adverse effects of thought control" in relation to the "need to control thoughts" as aggressive impulse: "I easily get angry when I feel irritated", "I always try to suppress my anger", "It is my weakness that I cannot control my anger", "I cannot control expressions of anger", "Expressing anger is bad", and "I can express anger in words that are not aggressive". The cfa confirmed that all of the items except for "I can express anger in words that are not aggressive" were closely associated with NC. The latter item showed a weak association at .05, which possibly resulted from the high rate of female participation (83\%). Previous researchers [23] found that receptive mitigation $(43 \%)$ was the most frequent anger expression pattern among female nursing students, who quietly internalized their anger rather than expressing it outwardly through words or actions and turned their anger expression into positive thoughts [9]. NC is associated with expressing aggressive impulses as anger [12,13], and the weak association with NC of the item "I can express anger in words that are not aggressive" likely arose because female nursing students are characterized by a refusal to express aggressive impulses outwardly.

CFA confirmed that all six items that loaded under factor 5, CSC, were closely associated: "I think a lot about my thoughts", "I am aware of the way my mind works when I am thinking through a problem", "I monitor my thoughts", "I am constantly aware of my thinking", "I pay close attention to the way my mind works", and "I constantly examine my thoughts". The CFA also indicated that the six CSC items were in the same context as the five MCRS subfactors in MCS; specifically, each of factors 1, 2, 3, and 5 was closely associated with all six items, and factor 4 was weakly associated with one item for the reason identified from literature review.

With regard to the general characteristics, we found no statistically significant differences in any subfactors for mean metacognition by gender or by education with the exception of POS. We conducted this study with nursing students, of whom $83 \%$ were female and $90 \%$ were high school graduates, and thus, it is difficult to know how generalizable these findings may be. It will be necessary to design a study with a more equitable gender ratio and greater diversity in education levels to better determine varia- tions in metacognitive beliefs by gender and education. Separately, in the correlation analysis of subfactors, all five were statistically significantly positively correlated with one another, in keeping with the findings from research on MCQ-30 [3] and from Turkish research [22]. The seven items that were corrected and supplemented in this study were one item under the second factor regarding anxiety and six items related to anger under the fourth factor. As for the second factor, which consisted of items related to anxiety, all items showed high correlations. At the time the MCQ-30 was developed, the fourth factor was "items about the need to control thoughts" and only three of six items showed high correlations in factor analysis. In this study, we revised and supplemented the items by focusing on the fourth factor, "adverse effects due to control of thoughts". The analysis revealed high relevance for five items, indicating partial improvement on the problems of the original scale, but one item still did not have high relevance, so repeated research and further analysis of the items are needed. In addition, because we conducted this study with solely nursing students, the results cannot be generalized; for generaliability, it will be necessary to repeat the study with different subjects in the future. Future research should test replicability of the factorial structure using CFA methods.

This study is significant in that we confirmed the reliability and validity of a revised version of the MCQ-30 that newly incorporated the concepts of anger and anxiety. Nursing students need to complete a high-intensity academic workload and require a wide-ranging understanding of nursing practices in preparation for their work as health care providers, and metacognition serves as an important variable of learning. Highly metacognitive students show higher academic achievement, and therefore, it might be desirable to determine and develop metacognitive competence among nursing students. Improving nursing students' metacognitive capabilities could have the twin aims of reducing any instability they might experience and improving their academic performance. This study has laid the foundation for utilizing our MCRS in academic guidance, personal counseling, and/or metacognition treatment interventions for nursing students.

\section{CONCLUSION}

With regard to reliability and validity, we confirmed that the MCRS comprised the same five subfactors as the related rating scales, the MCQ, MCQ-30, K-MCQ-30, and Turkish version of MCQ-30, and each factor was associated with its six items; therefore, we confirmed that the 
instrument was reliable and valid for evaluating metacognitive beliefs. We believe it might be desirable to be able to determine the metacognitive beliefs of nursing students and thus provide them with counseling and guidance aimed at improving their metacognitive competence for academic work, and we believe that the metacognition rating scale we developed can be used effectively for this purpose. However, as we noted earlier, the major limitation of this study is the restricted sample of nursing students, and care should be taken in generalizing the current results to other populations. We advise expanding on our findings by conducting further research in populations with a more even gender distribution and more diverse education backgrounds.

\section{CONFLICTS OF INTEREST}

The authors declared no conflicts of interest.

\section{ORCID}

Lee, Kyunghee

Heo, Youngjin

Han, Mihwa

Kim, Mijung

Choi, Hyunseok

https://orcid.org/0000-0002-8012-8914 https://orcid.org/0000-0003-0100-8701 https://orcid.org/0000-0002-6017-4876 https://orcid.org/0000-0002-3816-0101 https://orcid.org/0000-0002-4039-3086

\section{REFERENCES}

1. Pintrich PR, Smith D, Garcia T, McKeachie WJ. A manual for the use of the Motivated Strategies for Learning Questionnaire (MSLQ). Technical Report. Ann Arbor, Michigan, USA: National Center for Research to Improve Postsecondary Teaching and Learning; 1991. Report No. NCRIPTAL-91-B-004.

2. Flavell JH. Metacognition and cognitive monitoring: a new area of cognitive-developmental inquiry. American Psychologist. 1979;34(10):906-911.

https:// doi.org/10.1037/0003-066X.34.10.906

3. Wells A, Cartwright-Hatton S. A short form of the metacognitions questionnaire: properties of the MCQ-30. Behaviour Research and Therapy. 2004;42(4):385-396. https://doi.org/10.1016/S0005-7967(03)00147-5

4. Kim DH. Metacognition and problem solving ability among nursing students in Korea. Global Health Nursing. 2014;4(1): 11-17.

5. Stewart PW, Cooper SS, Moulding LR. Metacognitive development in professional educators. The Researcher. 2007;21(1):32-40.

6. Gibbons C, Dempster M, Moutray M. Stress, coping and satisfaction in nursing students. Journal of Advanced Nursing. 2011;67(3):621-632. https://doi.org/10.1111/j.1365-2648.2010.05495.x

7. Reeve KL, Shumaker CJ, Yearwood EL, Crowell NA, Riley JB.
Perceived stress and social support in undergraduate nursing students' educational experiences. Nurse Education Today. 2013;33(4):419-424.

https://doi.org/10.1016/j.nedt.2012.11.009

8. Taylor H, Reyes H. Self-efficacy and resilience in baccalaureate nursing students. International Journal of Nursing Education Scholarship. 2012;9(1):1-13. https://doi.org/10.1515/1548-923X.2218

9. Cha NH, Seo EJ. The relationship between anger expression and self-esteem in nursing college students. Journal of Korean Academy of Community Health Nursing. 2012;23(4):451-459. https://doi.org/10.12799/jkachn.2012.23.4.451

10. Huntley CD, Young B, Smith CT, Jha V, Fisher PL. Assessing metacognitive beliefs in test anxiety: Psychometric properties of the metacognitions questionnaire, 30 (MCQ-30) among university students. Current Psychology. 2020:1-9. https://doi.org/10.1007/s12144-020-00662-y

11. Matthews G, Wells A. Attention and emotion: a clinical perspective. Washington, DC, USA: American Psychological Association; 2016. p. 69-75.

12. Nagtegaal MH, Rassin E, Muris P. Aggressive fantasies, thought control strategies, and their connection to aggressive behaviour. Personality and Individual Differences. 2006;41(8):1397-1407. https://doi.org/10.1016/j.paid.2006.05.009

13. Lindemann E. Symptomatology and management of acute grief. American Journal of Psychiatry. 1944;101(2):141-148. https://doi.org/10.1176/ajp.101.2.141

14. Fisher P, Wells A. Metacognitive therapy: distinctive features. London, UK: Routledge; 2009. 152 p.

15. Cartwright-Hatton S, Wells A. Beliefs about worry and intrusions: the meta-cognitions questionnaire and its correlates. Journal of Anxiety Disorders. 1997;11(3):279-296. https://doi.org/10.1016/S0887-6185(97)00011-X

16. Faustino B, Branco Vasco A, Oliveira J, Lopes P, Fonseca I. Metacognitive self-assessment scale: psychometric properties and clinical implications. Applied Neuropsychology: Adult. 2019;28(5):596-606. https://doi.org/10.1080/23279095.2019.1671843

17. Klein D. I've seen this before? The effects of self-monitoring and multifile context instruction on knowledge representation and transfer among middle school students. Los Angeles, CA, USA: University of California; 1998. p. 26-27.

18. Schraw G, Dennison RS. Assessing metacognitive awareness. Contemporary Educational Psychology. 1994;19(4):460-475. https://doi.org/10.1006/ceps.1994.1033

19. Lee JH. Analysis of the structural relationships among self-determination motivation to learn, metacognition, self-directed learning ability, learning flow, and school achievement. Korean Journal of Educational Research. 2010;48(2):67-92.

20. Seol SH. Cognitive appraisals and control strategies on worry 
and obsession [master's thesis]. [Seoul]: Seoul National University; 2004. $154 \mathrm{p}$.

21. Cho Y, Jahng S, Chai S. The factor structure and concurrent validity of the Korean version of the metacognitions questionnaire 30 (K-MCQ-30). Journal of Clinical Psychology. 2012;68 (3):349-391. https://doi.org/10.1002/jclp.20867

22. Yılmaz AE, Gençöz T, Wells A. Psychometric characteristics of the Penn State Worry Questionnaire and Metacognitions Questionnaire-30 and metacognitive predictors of worry and obsessive-compulsive symptoms in a Turkish sample. Clinical Psychology \& Psychotherapy: An International Journal of Theory \& Practice. 2008;15(6):424-439.

https://doi.org/10.1002/cpp.589

23. Lee EJ, Park EN. Exploration of anger expression patterns of female nursing students using $Q$ methodology. Journal of Fisheries and Marine Sciences Education. 2015;27(3):682-695. https://doi.org/10.13000/JFMSE.2015.27.3.682 


\section{부록 1. 메타인지평가척도}

* 본 설문지는 사람들이 자신의 생각에 대해 가지고 있는 신념을 나타낸 것입니다. 각 문항은 사람들이 표현하는 신념을 제시한 것으로 문항을 읽고 귀하가 동의하는 정도를 나타내는 곳에 $\bigcirc$ 표 하십시오. 모든 항목에 응답해야 하며 정답이나 오답은 없습니다.

\begin{tabular}{|c|c|c|c|c|c|c|}
\hline 번호 & 항목 & $\begin{array}{c}\text { 전혀 } \\
\text { 동의하지 } \\
\text { 않는다 }\end{array}$ & $\begin{array}{c}\text { 약간 } \\
\text { 동의한다 }\end{array}$ & $\begin{array}{l}\text { 중간정도 } \\
\text { 동의한다 }\end{array}$ & $\begin{array}{c}\text { 상당히 } \\
\text { 동의한다 }\end{array}$ & $\begin{array}{l}\text { 전적으로 } \\
\text { 동의한다 }\end{array}$ \\
\hline 1 & 미리 걱정하고 있어야 미래를 대비할 수 있고, 그래야 안심할 수 있다. & & & & & \\
\hline 2 & 일상의 모든 것이 걱정거리가 된다. & & & & & \\
\hline 3 & 아무리 생각을 그만두려고 해도 걱정이 멈추어지지 않는다. & & & & & \\
\hline 4 & 걱정에 중독이 되면 사소한 스트레스조차 불안이 된다. & & & & & \\
\hline 5 & 어떤 문제에 대해 생각할 때 내 마음이 어떤식으로 움직여가는지 잘 알고 있다. & & & & & \\
\hline 6 & 나는 조금만 기분이 거슬리면 쉽게 분노를 느끼게 된다. & & & & & \\
\hline 7 & 나는 겁이 많고 안정을 중시한다. & & & & & \\
\hline 8 & 나는 내가 다른 사람보다도 기억력이 떨어진다고 느낀다. & & & & & \\
\hline 9 & 내가 중단하려고 노력해도 걱정을 계속하고 있다. & & & & & \\
\hline 10 & 나는 매사에 조심을 해야 안심이 된다. & & & & & \\
\hline 11 & 나는 걱정을 무시할 수 없다. & & & & & \\
\hline 12 & 나는 내 생각을 자주 검토한다. & & & & & \\
\hline 13 & 나는 분노를 항상 억압하려 한다. & & & & & \\
\hline 14 & 나는 실제와 다르게 잘못 기억할 수 있다. & & & & & \\
\hline 15 & 나는 걱정으로 화나게 될 수 있다. & & & & & \\
\hline 16 & 나는 끊임없이 내 생각을 느끼고 있다. & & & & & \\
\hline 17 & 나는 기억력이 좋지 않다. & & & & & \\
\hline 18 & 나는 내 생각에 몰두해 정신이 팔리곤 한다. & & & & & \\
\hline 19 & 항상 걱정하면서 조심스러운 대처가 도움이 된다. & & & & & \\
\hline 20 & 내가 분노를 통제할 수 없는 것은 나의 약점이다. & & & & & \\
\hline 21 & 나는 걱정을 시작하면 멈출 수 없다. & & & & & \\
\hline 22 & 나는 분노를 표출하는 것을 조절하지 못한다. & & & & & \\
\hline 23 & 비관적인 생각을 많이 하는 것이 문제를 해결하는데 도움이 된다. & & & & & \\
\hline 24 & 나는 장소에 대한 내 기억에 확신이 거의 없다. & & & & & \\
\hline 25 & 분노를 표현하는 것은 나쁘다. & & & & & \\
\hline 26 & 나는 나의 기억을 신뢰하지 않는다. & & & & & \\
\hline 27 & 나는 공격적이지 않은 언어로 분노를 전달할 수 있다. & & & & & \\
\hline 28 & 나는 일처리를 할 때 조심성스럽게 위험한 상황에 잘 대비한다. & & & & & \\
\hline 29 & 나는 내 행동에 대한 기억에 확신이 거의 없다. & & & & & \\
\hline 30 & 나는 내 생각에 집중한다. & & & & & \\
\hline
\end{tabular}

